\title{
Ilmenite as a recorder of the kimberlite history from mantle to surface: examples from Indian kimberlites
}

\author{
J. Xu' ${ }^{1}$, J. C. Melgarejo ${ }^{2}$ and M. Castillo-Oliver ${ }^{3}$ \\ ${ }^{l}$ Departament de Mineralogia, Petrologia i Geologia Aplicada, Facultat de Ciències de la Terra, Universitat \\ de Barcelona, Barcelona, Spain, jingyao.xu@ub.edu \\ ${ }^{2}$ Departament de Mineralogia, Petrologia i Geologia Aplicada, Facultat de Ciències de la Terra, Universitat \\ de Barcelona, Barcelona, Spain, joan.carles.melgarejo.draper@ub.edu \\ ${ }^{3}$ ARC Centre of Excellence for Core to Crust Fluid Systems and GEMOC, Department of Earth and Planetary \\ Sciences, Macquarie University, NSW, Australia,montgarri.castillo-oliver@mq.edu.au
}

\section{Introduction}

Indian kimberlites occur in the Bastar craton (Central India) and in the Eastern Dharwar craton (EDC) Southern India. Nearly 100 kimberlite pipes have been discovered in the Eastern Dharwar craton of southern India, and they are distributed in three distinct fields: 1) the southern Wajrakarur kimberlite field (WKF); 2) the northern Narayanpet kimberlite field (NKF); and 3) the Raichur kimberlite field (RKF) (Chalapathi Rao et al, 2013). Nine kimberlites have been selected for this study: three came from the Siddanpalli cluster of RKF (SK-1, SK-2 and SK-3); other six kimberlites came from WKF, from Chigicherla (CC-4 and CC-5), Kalyandurg (KL-3 and KL-4), Lattavaram (P-3) and Mulligripally (P-5). The kimberlite emplacement took place during the Mesoproterozoic, around 1.1 Ga (Chalapathi Rao et al., 2013). Ilmenite is one of the classic diamond indicator minerals (DIMs) and for long it has been used as a guide for kimberlite exploration. The aim of this study is to evaluate the petrogenetic information that can be provided from the textural and geochemical study of the different ilmenite generations present in the Indian kimberlites studied in this work.

\section{Petrography of ilmenite}

Ilmenite crystals from the Indian kimberlites are not formed in a single process, and many ilmenite populations can be distinguished. The next textural-compositional types of ilmenite are defined based on petrographic and compositional studies using optical petrography and SEM-EDS: 1) Mg-rich polycrystalline ilmenite xenoliths scattered in the kimberlite groundmass, with compositions in the ilmenite s.s. field; 2) rounded macro-microcrysts of ilmenite scattered in kimberlite groundmass with similar compositions to those indicated above; 3) Mg-very rich ilmenite replacing chromite and other Ti-bearing xenocrysts and type 1 and 2 ilmenite xenocrysts, with compositions in the geikielite field; 4) Mg-rich ilmenite as subhedral thin platelets restricted to fully bastitized pyroxene macrocrysts; 5) late anhedral Mn-rich ilmenite replacing either rutile xenocrysts or type 2 ilmenite and being replaced by perovskite and ulvöspinel; and 6) very late euhedral tabular to anhedral Mn-rich ilmenite associated with calcite and chlorite replacing perovskite and ulvöspinel.

\section{Composition of ilmenite}

The classification of the ilmenite types, in terms of the modal proportions of the end members of the ilmenite-hematite-geikielite-pyrophanite series, shows that most of them are ilmenite s.s., except for the type 3 ilmenite, which plots in the geikielite domain (Fig. 1A). The hematite component is never higher than $15 \%$, and in most cases it remains below $10 \%$. The pyrophanite component is enriched in types 5 and 6. However, the Mn content in these late ilmenite types is lower than 0.3 apfu. The compositional ranges of type 1 and type 2 are very similar in terms of their $\mathrm{Fe}^{2+} / \mathrm{Mg}$ ratio, with $\mathrm{Mg}$ apfu values between 0.2 and 0.45 , within the ilmenite s.s. field. Their $\mathrm{Mn}$ and $\mathrm{Fe}^{3+}$ contents remain low (less than $0,1 \mathrm{apfu}$ ) (Fig. 1B).

Correlations between the major components in different types ilmenites are presented in figure 2. As expected, there is a good negative correlation between $\mathrm{Ti}$ and $\mathrm{Fe}^{3+}$. The highest $\mathrm{Fe}^{3+}$ values are found in the primary ilmenite generations (types 1 and 2) and the lowest ones in the late generations (types 5 
and 6, Fig. 2A). These younger ilmenite generations have the lowest contents in $\mathrm{MgO}$ in all the field (Fig. 2B). There is a positive correlation between $\mathrm{TiO}_{2}$ and $\mathrm{MgO}$ (type 1, 2 and 3 Fig. 2B). As shown in figure $2 \mathrm{~B}$, most Mn-rich ilmenite crystals plot outside the classic kimberlite domain in the $\mathrm{TiO}_{2}-\mathrm{MgO}$ diagram of Wyatt et al. (2004). The $\mathrm{Fe}^{3+}$ contents in Mn-rich ilmenite (type 5 and 6) are relatively low (less than $0.15 \mathrm{apfu}$ ), while Mg-rich ilmenite and geikielite (types 1 to 4 ) have $\mathrm{Fe}^{3+}$ content between 0 and 0.4 apfu. Mn-ilmenite (type 5 and 6) has higher $\mathrm{Fe}^{2+}$ content than Mg-ilmenite (type 1 to 4); they also tend to decrease in $\mathrm{Fe}^{2+}$ owing to the substitution of $\mathrm{Fe}^{2+}$ by $\mathrm{Mn}^{2+}$.

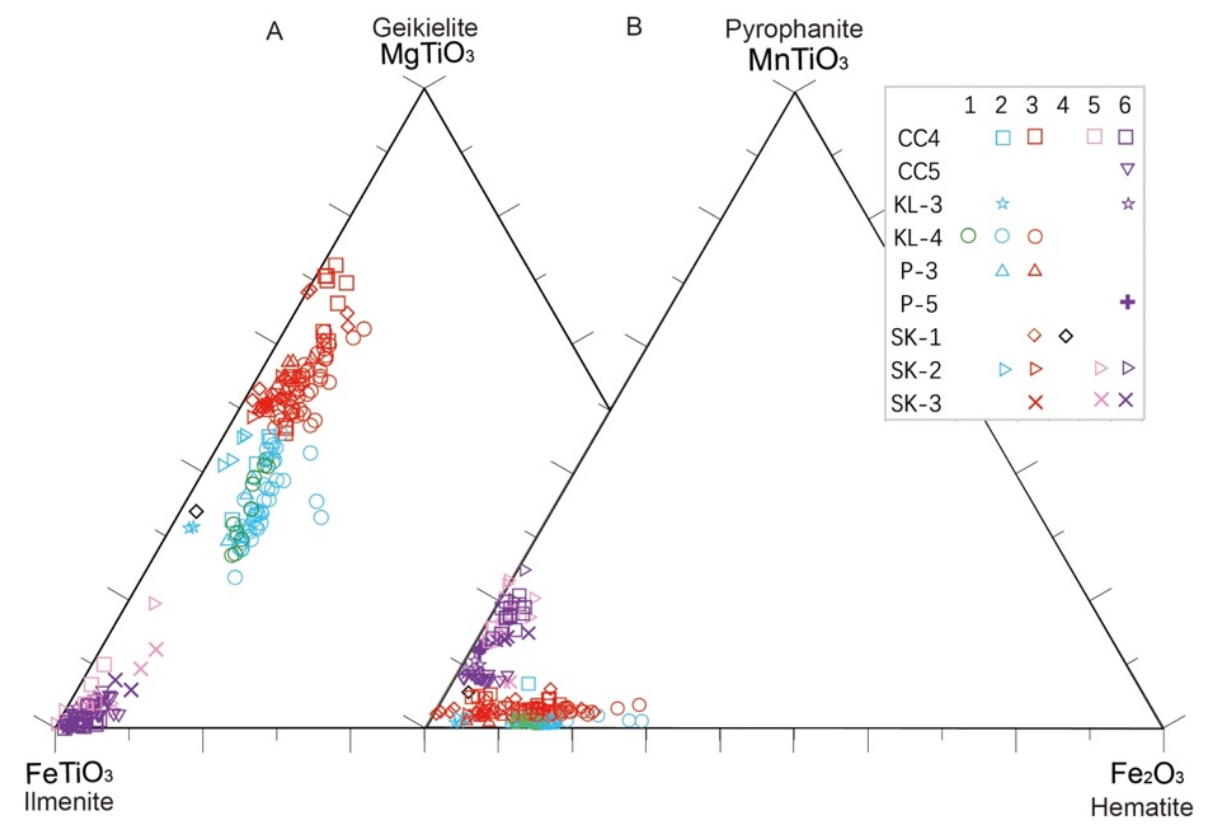

Figure 1: Compositions of the different textural types (type 1 to 6 ) of ilmenite from different Indian kimberlites: (A) in terms of the geikielite $\left(\mathrm{MgTiO}_{3}\right)$-ilmenite $\left(\mathrm{FeTiO}_{3}\right)$-hematite $\left(\mathrm{Fe}_{2} \mathrm{O}_{3}\right)$; $(\mathrm{B})$ in terms of the pyrophanite $\left(\mathrm{MnTiO}_{3}\right)$-ilmenite $\left(\mathrm{FeTiO}_{3}\right)$-hematite $\left(\mathrm{Fe}_{2} \mathrm{O}_{3}\right)$ endmembers.
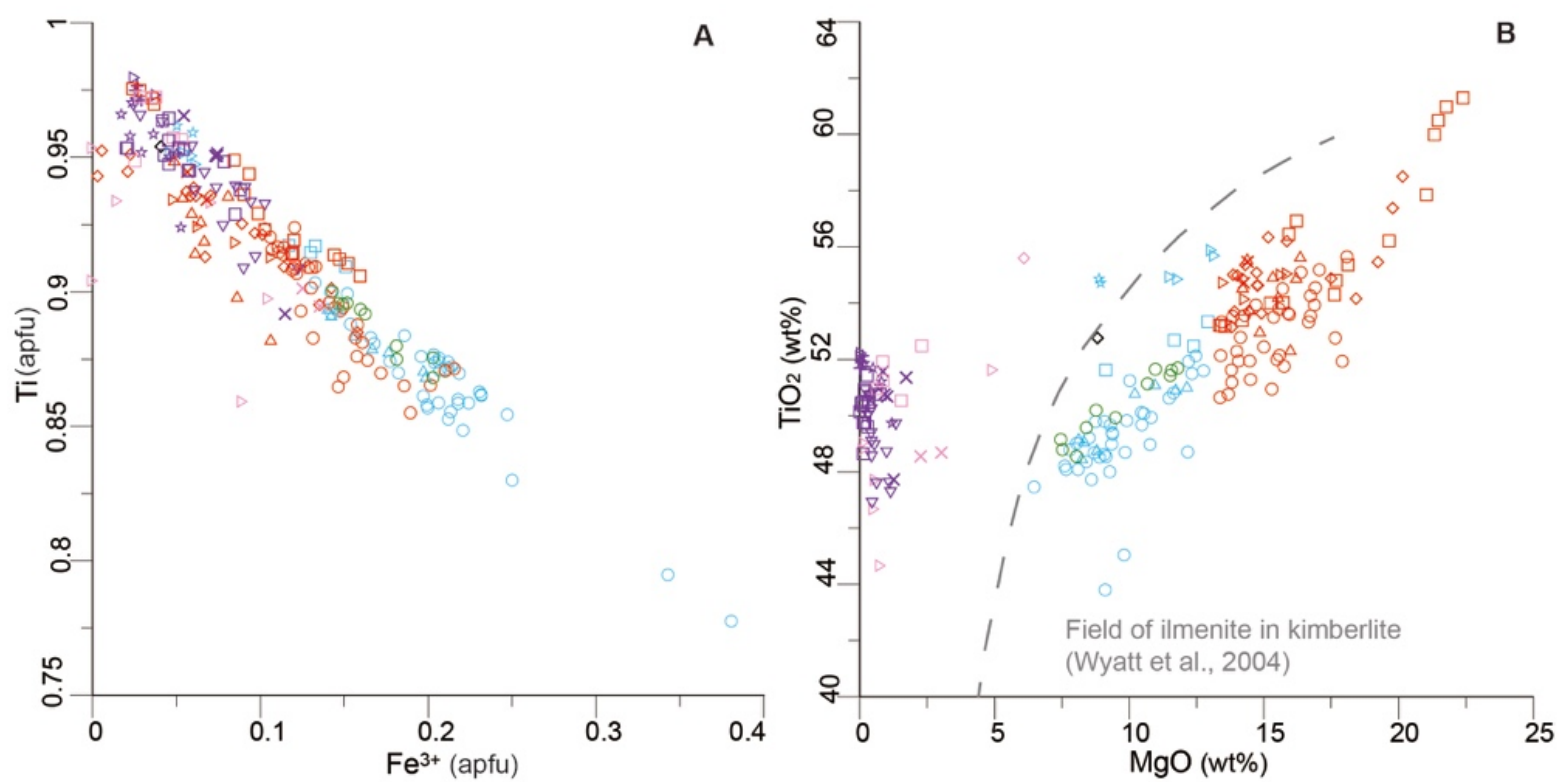

Figure 2: Correlation between major elements for the different types of ilmenite. Legend is indicated in the figure 1.

Significant differences in the $\mathrm{Nb}$ content are found among the different textural types. Very low $\mathrm{Nb}$ values are common in the older ilmenite generations (types 1 and 2), with only slight $\mathrm{Nb}$ enrichment in some type 3, 4, 5 and 6 ilmenites. However, both type 5 and type $6 \mathrm{Mn}$-rich ilmenite are enriched in $\mathrm{Nb}$ when they replace $\mathrm{Nb}$-rich rutile and $\mathrm{Nb}$-rich perovskite, respectively. Type 1 and 2 ilmenite have very 
low contents in $\mathrm{Cr}$, and type 3 ilmenite is also poor in this element when it replaces previous ilmenite crystals. However, type 3 ilmenite is enriched in $\mathrm{Cr}$ when it replaces chromite and other $\mathrm{Cr}$-rich minerals.

\section{Discussion}

Up to 6 compositional-textural types of ilmenite can be distinguished in the Indian kimberlites studied in this work. These ilmenite generations record different processes in the kimberlite history, from mantle to surface. A first generation of polycrystalline Mg-rich ilmenite (type 1 ilmenite) was produced by metasomatic processes in the mantle before the emplacement of the kimberlite. Type 2 ilmenite was produced by disaggregation of these polycrystalline aggregations, resulting in rounded megacrysts (type 2 ilmenite) with a composition similar to the the first generation. Interaction with evolved supercritical fluids produced the replacement of the pre-existing ilmenite megacrysts and aggregates by a new generation of geikielite (type 3 ilmenite) along grain boundaries and cracks. Type 3 ilmenite may also replace other oxides, and the composition of this ilmenite generation is highly dependent on the composition of the replaced minerals. Hence, ilmenite replacing other ilmenite crystals is not much enriched in minor elements, but when ilmenite is replacing Cr-rich minerals it becomes distinctly enriched in $\mathrm{Cr}$. Another generation of $\mathrm{Mg}$-rich ilmenite could be produced by exsolution processes (type 4 ilmenite) but the nature of the host crystals remains obscure, although they are likely enstatite. The late ilmenite generations are characterized by an enrichment in Mn, but two generations can be distinguished based on their stage of formation. Type 5 ilmenite is produced before the crystallization of perovskite and ulvöspinel from the groundmass, and it usually mantles ilmenite and other Ti-rich minerals. Again, the contents of minor elements depend on the replaced mineral; when it is ilmenite, the newly formed ilmenite has no significant contents of minor elements. However, when ilmenite replaces $\mathrm{Nb}$-rutile, it becomes enriched in $\mathrm{Nb}$. Finally, type 6 ilmenite is produced after the crystallization of the groundmass minerals and it replaces them. This ultimate ilmenite has similar behaviour in terms of enrichment in minor elements as in the above examples. Hence, when type 6 ilmenite replaces ulvöspinel it does not have enrichment in minor elements; in contrast, when type 6 ilmenite replaces $\mathrm{Nb}$-rich perovskite it is enriched in $\mathrm{Nb}$.

The composition of the primary ilmenite generations is different to those found as inclusions in kimberlite diamonds from Yakutia (Sobolev et al., 1997). The higher contents in $\mathrm{Mg}$ are recorded in metasomatic ilmenite which is produced during kimberlite emplacement, and cannot be associated with the diamond formation. The higher Mn contents are linked to late processes clearly produced after the crystallization of the kimberlite groundmass, and therefore the Mn enrichments cannot be used to establish the diamond grade of the kimberlite.

\section{Acknowledgments}

This research was supported the AGAUR 2014SGR01661 of the Generalitat de Catalunya and a FI grant to J. Xu (coded FI_B 00904) sponsored by the Departament d'Educació i Universitats de la Generalitat de Catalunya. The authors also acknowledge the Servei de Làmina Prima (thin section preparation laboratory) and the Centres Científics i Tecnològics de la Universitat de Barcelona (CCiTUB) for the assistance with SEM-BSE-EDS study (Dr. F. J. García-Veigas, D. Artiaga) and EMP analyses (Dr. Xavier Llovet).

\section{References}

Chalapathi Rao NV, Wu FY, Mitchell RH, Li QL, Lehmann B (2013) Mesoproterozoic U-Pb ages, trace element and $\mathrm{Sr}-\mathrm{Nd}$ isotopic composition of perovskite from kimberlites of the Eastern Dharwar craton, southern India: distinct mantle sources and a widespread $1.1 \mathrm{Ga}$ tectonomagmatic event. Chem. Geol. 353: 48-64

Wyatt BA, Mike B, Anckar E, Grütter H (2004) Compositional classification of "kimberlitic" and "nonkimberlitic" ilmenite. Lithos 77: 819-840

Sobolev NV, Kaminsky FV, Griffin WL, Yefimova ES, Win TT, Ryan CG, Botkunov AI (1997) Mineral inclusions in diamonds from the Sputnik kimberlite pipe, Yakutia. Lithos 39: 135-157 